J. Clin. Chem. Clin. Biochem.

Vol. 25, 1987, pp. 893-899

(C) 1987 Walter de Gruyter \& Co.

Berlin - New York

\title{
Standardization of an Enzymometric Assay for Apolipoprotein A-I by Using Mixtures of Monoclonal Antibodies ${ }^{1}$ )
}

\author{
By Christine Betard, Ngoc Vu-Dac, Hafid Mezdour
}

Service de Recherche sur les Lipoprotéines et l'Athérosclérose, Institut Pasteur, Lille, France Département Lipides, Lipoprotéines et U. Inserm 279, Faculté de Pharmacie, Lille, France

\section{A. Christine Nestruck}

Institut de Recherches Cliniques, Montreal, Qué., Canada

\section{A. Leroy and J.-Ch. Fruchart}

Service de Recherche sur les Lipoprotéines et l'Athérosclérose, Institut Pasteur, France Département Lipides, Lipoprotéines et U. Inserm 279, Faculté de Pharmacie, Lille, France

(Received March 30/October 1, 1987)

Summary: For the standardization of human plasma apolipoprotein A-I assay two well characterized monoclonal antibody mixtures were used to develop a sandwich immunoenzymometric assay. The monoclonal antibody mixture 1 (A05-A17-A30) in solid phase technique was selected on the basis of its higher binding capacity of [ $\left.{ }^{125} \mathrm{I}\right] \mathrm{HDL}$ (41 ng per well) compared to polyclonal antibody ( $23 \mathrm{ng}$ per well). The epitopes recognized by monoclonal antibody mixture 1 are surface antigenic sites of apolipoprotein A-I expressed on native HDL as determined by competitive imhibition of labeled HDL. The peroxidase conjugated monoclonal antibody mixture 2 (A03-A05-A17-A51) was selected on the basis of its ability to bind to apolipoprotein AI captured by monoclonal antibody mixture 1 . For this, we used the ${ }^{125}$ I-labeled monoclonal antibodies.

Under optimized assay conditions, the immunoenzymometric assay is precise (intra- and inter-assay coefficients of variations $5.4 \%$ and $9.2 \%$ respectively). It yields plasma apolipoprotein A-I values that correlate highly with those obtained with polyclonal antibody $(r=0.96)$. So the use of well characterized monoclonal antibody mixtures reacting only to surface antigenic sites of apolipoprotein A-I present on native lipoprotein may provide the possibility of standardization of apolipoprotein A-I measurement.

\section{Introduction}

Recently, numerous studiès have demonstrated a decrease in apolipoprotein A-I in subjects with coronary artery disease $(1-6)$. Several techniques have been used in the measurement of circulating apolipoprotein A-I, including radial immunodiffusion (7), elèctroimmunoassay (8), radioimmunoassay (9), immunonephelometry (10) and more recently enzyme linked immunoassay (ELISA) $(11,12)$.

\footnotetext{
1) This work was supported by Grant of CNAMTS - Inserm $\mathrm{n}^{\circ}$ 86-3-42-7-E.
}

The potential advantages of the enzymometric assay are numerous: high sensitivity, specificity, flexibility as well as no need for radioactive tracers. This assay could be considered as a possible reference method (12), but in the standardization of apolipoprotein immunoassay careful attention must be paid not only to the methodology, but also to the selection of antibodies.

Some examples of how plasma apolipoprotein A-I values vary with differing antisera have been reported $(13,14)$; it is therefore particularly important that the antibodies used react with the same antigenic deter- 
minants at all times. Recommendations by the Working Group on Antibodies of the NIH Workshop on Apolipoprotein Quantification outline the potential interest of mixtures of monoclonal antibodies (15). In this paper, we describe a sandwich enzymometric assay for human plasma apolipoprotein A-I using two well selected mixtures of monoclonal antibodies for both the immobilized and conjugated antibodies.

\section{Materials and Methods}

Plasma samples and lipoprotein isolation

Human blood samples were obtained by venipuncture after an overnight fast from "Centre de Médecine Préventive, Institut Pasteur, Lille". We also included in this study hyperlipidaemic patients with triacylglycerol values greater than $1500 \mathrm{mg} / \mathrm{l}$ and cholesterol values greater than $2500 \mathrm{mg} / \mathrm{l}$. Samples were collected into tubes containing $0.5 \mathrm{ml}$ of $5 \mathrm{mmol} / 1 \mathrm{EDTA}$ and centrifuged to eliminate cells. Total cholesterol and triacylglycerols were measured in fresh plasma and apolipoprotein A-I was always quantified within $48 \mathrm{~h}$ after addition of preservatives as previously described (16).

Using standard ultracentrifugation techniques, as described by Havel et al. (17), we isolated HDL $(\mathrm{d}=1.063-1.210 \mathrm{~kg} / \mathrm{l})$, $\mathrm{HDL}_{2}(\mathrm{~d}=1.063-1.100 \mathrm{~kg} / \mathrm{l})$ and $\mathrm{HDL}_{3}(\mathrm{~d}=1.100-1.120$ $\mathrm{kg} / \mathrm{l}$ ) from pooled fresh plasma. Apolipoprotein A-I was isolated by "Fast Protein Liquid Chromatography" from HDL apolipoproteins using a MonoQ Column (Pharmacia) and its purity was confirmed by SDS gels and amino acid analysis (18). The purified protein served as immunogen for the production of polyclonal antiserum.

Production and assessment of monoclonal antibodies to apolipoprotein A-I

A male Balb/C mouse was immunized intraperitoneally on day 0 with $500 \mu \mathrm{g}$ of $\mathrm{HDL}_{3}$ emulsified in $300 \mu \mathrm{l}$ of complete Freund's adjuvant and on day 21 , with the same dose of $\mathrm{HDL}_{3}$, in incomplete Freund's adjuvant. Two months later, at 10 days before cell fusion, $300 \mu \mathrm{g}$ of $\mathrm{HDL}_{3}$ in incomplete Freund's adjuvant was administered intraperitoneally and 3 days prior to fusion $300 \mu \mathrm{g}$ of $\mathrm{HDL}_{3}$ was injected intravenously. We used the $\mathrm{HDL}_{3}$ as immunogen since this major subfraction of the HDL does not contain the $\mathrm{Lp}(\mathrm{a})$.

As described by Campbell (19), spleen cells were fused with myeloma line SP2-O in the presence of polyethyleneglycol 1450 (Kodak) containing dimethylsulphoxide (Sigma), volume fraction 0.1. The cells were distributed in microtiter plates. Hybridomas were screened for the secretion of specific antibodies by ELISA (20) using microtiter plates coated with apolipoprotein A-I or $\mathrm{HDL}_{3}$ and rabbit anti-mouse immunoglobulin conjugated with horseradish peroxidase (Nordic).

Positive wells were cloned twice by limiting dilution. Ascites fluid was prepared by intraperitoneal injection of $2-4 \cdot 10^{5}$ hydridoma cells. Purification of antibodies was performed by ammonium sulphate precipitation and affinity chromatography on Protein A-Sepharose (Pharmacia).

In order to determine antibody specificity, immunoblotting was performed as described by Towbin et al. (21). Apolipoproteins from HDL were separated by SDS polyacrylamide gel electrophoresis, transfered to nitrocellulose and incubated with monoclonal antibody mixtures and polyclonal antibodies $(15 \mathrm{mg} / \mathrm{l})$ diluted in Tris $15 \mathrm{mmol} / 1, \mathrm{NaCl} 0.15 \mathrm{~mol} / \mathrm{l}$, Tween $0.5 \mathrm{ml} / 1$, pH
8.0. Molecular weight standards (Pharmacia) were used for calibration. The bound antibodies were detected with peroxidase-labeled rabbit anti-mouse and goat anti-rabbit immunoglobulins.

Characterization of the monoclonal antibodies and selection for the synthetic polyclonal

HDL were labeled with $\mathrm{Na}^{125} \mathrm{I}$ using iodine monochloride (22). The specific activity of the [125I]HDL was 680 counts/min $\cdot n g$ protein. Fourteen monoclonal antibodies were iodinated using chloramine $T$ (23). The specific activity ranged from 1250 counts/min $\cdot \mathrm{ng}$ to 1610 counts/min $\cdot \mathrm{ng}$ protein.

To assess the ability of labeled monoclonal antibodies to reveal lipoprotein particles bound to an immobilized monoclonal antibody, flexible microtiter plates (Falcon F3911) were coated with one monoclonal antibody (A05, A17 or A30) and $100 \mu l$ of $\mathrm{HDL}$ ranging from 0.1 to $10 \mathrm{mg} / \mathrm{l}$ was added and incubated for 2 hours at $37^{\circ} \mathrm{C}$. After washing with phosphate buffered saline (containing $\mathrm{NaCl} 0.15 \mathrm{~mol} / \mathrm{l}, \mathrm{pH} 7.4$ ), $100 \mu \mathrm{l}$ of one ${ }^{125 \mathrm{I}}$ labelled monoclonal antibody (A03, A05, A17 or A51) containing 100000 counts/min was added and incubated for 2 hours at $37^{\circ} \mathrm{C}$. The wells were washed with phosphate buffered saline, cut and counted.

In order to study the binding and competitive displacement of [ ${ }^{125}$ I]HDL, polystyrene microtiter plates (Costar 3590 USA) were coated with $100 \mu \mathrm{l}$ of a mixture of monoclonal antibodies (mixture 1: A05-A17-A30, ratio $1: 1: 1) 15 \mathrm{mg} / \mathrm{l}$ in phosphate buffered saline overnight at room temperature, then blocked by bovine serum albumin $10 \mathrm{~g} / 1$ for 1 hour. Bovine serum albumin $10 \mathrm{~g} / \mathrm{l}$ was added to $100 \mu \mathrm{l}$ of [ $\left.{ }^{125} \mathrm{I}\right] \mathrm{HDL}$ (ranging from 0.5 to $5 \mathrm{mg} / 1$ in phosphate buffered saline) and incubated for 2 hours at $37^{\circ} \mathrm{C}$. Competitive displacement of [ $\left.{ }^{125}\right] \mathrm{HDL}$ was investigated as follows: $50 \mu \mathrm{l}$ of $\left.{ }^{125} \mathrm{~T}\right] \mathrm{HDL}$ at $7 \mathrm{mg} / 1$ and $50 \mu \mathrm{l}$ of increasing amounts of competitors (pooled plasma, HDL or pure apolipoprotein A-I ranging from 0.1 to $100 \mathrm{mg} / \mathrm{l}$ ) were incubated for 2 hours. The free [ $\left.{ }^{125} \mathrm{I}\right] \mathrm{HDL}$ was aspirated and counted in a gamma spectrometer.

\section{Immunoenzymometric assay}

Monoclonal antibodies A03, A05, A17 and A51 were chosen for labeling for inclusion in the mixture of labeled monoclonal antibodies. Each antibody $(5 \mathrm{mg})$ was labeled separately with horseradish peroxidase $(2.5 \mathrm{mg}$ ) (Boehringer Mannheim, West Germany) as previously described (16). Labeled antibodies were stored at $-20^{\circ} \mathrm{C}$ with an equal volume of glycerol.

Polystyrene microtiter plates (Costar 3590) were coated for 16 hours at room temperature with $100 \mu \mathrm{l}$ of monoclonal antibody mixture 1 (A05-A17-A30, ratio $1: 1: 1$ ) at $15 \mathrm{mg} / 1$ in phosphate buffered saline. The wells were washed four times with phosphate buffered saline. For the standard curve, we used a pool of plasma which had been calibrated as recommended by Fesmire et al. (14).

Standards were diluted with phosphate buffered saline to give final concentrations of $10-150 \mu \mathrm{g} / \mathrm{l}$ apolipoprotein $A-I$ and the plasma samples were diluted 15000 and 25000 fold. Samples or standards $(100 \mu \mathrm{l})$ were added to the wells and incubated at $37^{\circ} \mathrm{C}$ for 2 hours. After washing, $100 \mu$ l of horseradish peroxidase-conjugated monoclonal antibody mixture 2(A03 + A05 $\mathrm{A} 17$ + A51, ratio $1: 1: 1: 1$ ) diluted 15000-fold in phosphate buffered saline-bovine serum albumin $(10 \mathrm{~g} / \mathrm{l})$ were added and incubated 2 hours at $37^{\circ} \mathrm{C}$. After washing with phosphate buffered saline, $100 \mu \mathrm{l}$ of substrate solution was added to the wells. The substrate was 0 -phenylene diamine $(3 \mathrm{~g} / 1$ in citratephosphate $0.1 \mathrm{~mol} / 1 \mathrm{pH} 5.5$ and concentrated $\mathrm{H}_{2} \mathrm{O}_{2} 0.64 \mathrm{ml} / \mathrm{l}$ ). We allowed the colour to develop at room temperature for 30 minutes and the reaction was stopped by $100 \mu \mathrm{l}$ of $1 \mathrm{~mol} / 1 \mathrm{HCl}$, the absorbance was read at $492 \mathrm{~nm}$. 


\section{Results}

Characterization of monoclonal antibody mixtures

From a single cell fusion, fourteen clones that secreted anti-apolipoprotein A-I were selected. To develop the immunoenzymometric assay, we selected a panel of five monoclonal antibodies which recognized five individual epitopes of apolipoprotein A-I on the HDL particles. The immobilized monoclonal antibody mixture 1 (A05-A17-A30) in solid-phase was used to capture apolipoprotein A-I-containing lipoproteins in plasma, and horseradish peroxidase-labeled monoclonal antibody mixture 2 (A03-A05-A17-A51) was used to quantify the bound apolipoprotein A-I. First, we determined the specificity of monoclonal antibodies against apolipoprotein A-I-HDL by immunoblotting (fig. 1). In order to determine whether antibodies become bound to different antigenic sites on apolipoprotein A-I, the ability of each unlabeled antibody to compete with the ${ }^{125}$ I-labeled antibody for binding to apolipoprotein A-I was assessed. The data (not shown) indicated that the antibodies A03, $\mathrm{A} 05, \mathrm{~A} 17, \mathrm{~A} 30$ and $\mathrm{A} 51$ recognized different epitopes of apolipoprotein A-I.

\section{Immobilized monoclonal antibody mixture 1}

To evaluate the capacity of the solid-phase monoclonal antibody to bind to HDL, Scatchard analysis

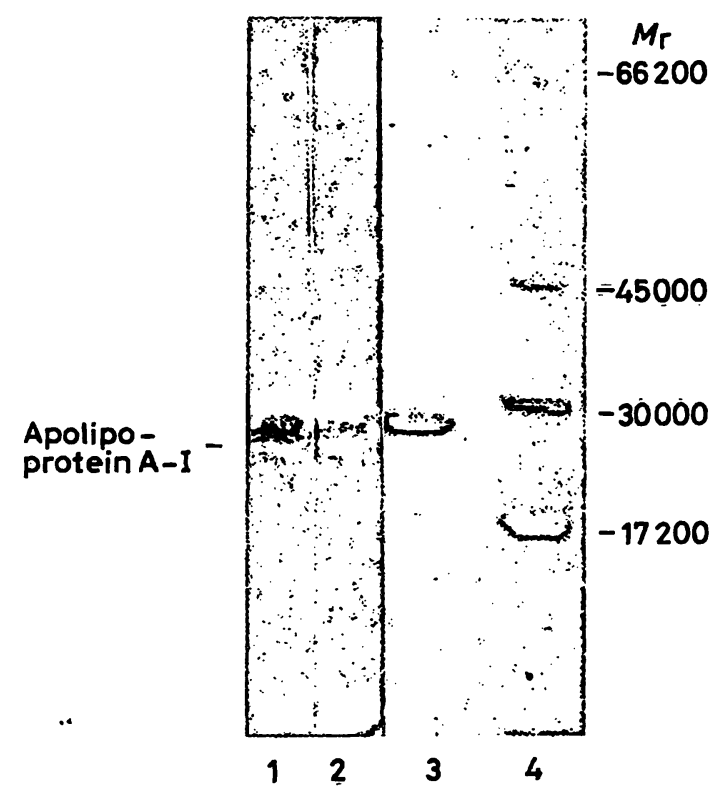

Fig. 1. Western blots using different antibody preparations 1: HDL; Mixture of monoclonal antibodies A30, A05, A17 against apolipoprotein A-I

2: HDL; Polyclonal antiserum against apolipoprotein A-I

3: Stained electropherogram of purified apolipoprotein A-I

4: Stained electropherogram of marker proteins for $M_{r}$ estimation of the binding capacity was performed using ${ }^{125} \mathrm{I}$ labeled HDL. The monoclonal antibody mixture 1 (A05-A17-A30) had a higher antigen binding capacity (41 ng HDL per well) than polyclonal antibody (23 ng HDL per well) (fig. 2).

To determine the expression of the apolipoprotein AI epitopes recognized by the immobilized monoclonal antibody mixture 1, purified (delipidated) apolipoprotein A-I, HDL and plasma were studied for their ability to displace ${ }^{125}$ I-labeled HDL in solid-phase. Slope analysis of the logit-transformed competitive curves (fig. 3 ) indicated that the epitopes recognized

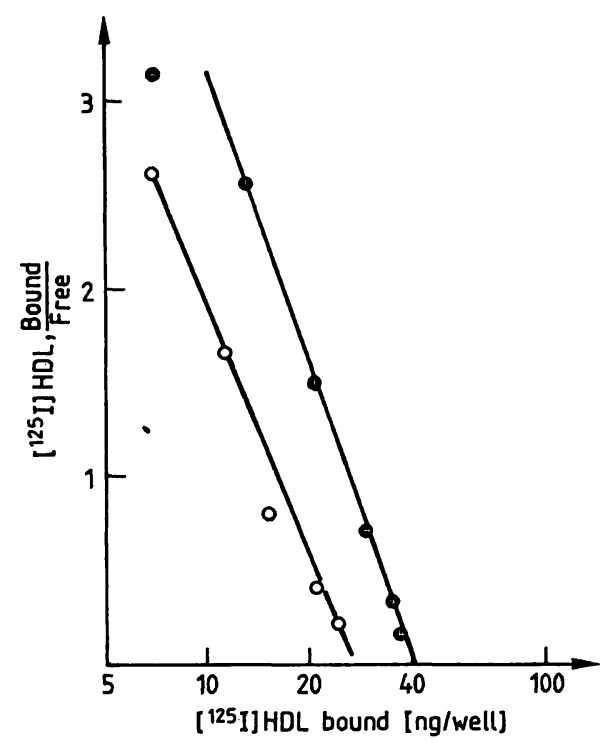

Fig. 2. Scatchard plot

- - 0 mixture 1 of monoclonal antibodies: A05, A17, A30

○-० polyclonal antiserum

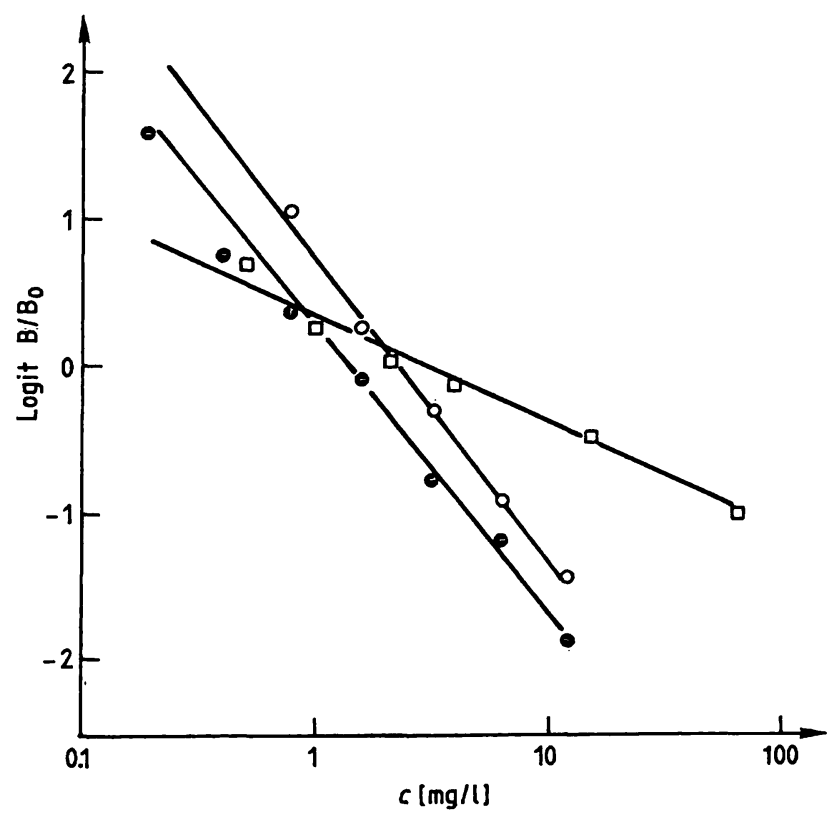

Fig. 3. Competitive inhibition of binding of $\left[{ }^{125}\right] \mathrm{HDL}$ to immobilized monoclonal antibody mixture 1: A05, A17, A30 by

$0-0 \mathrm{HDL}$,

$\square-\square$ apolipoprotein A-I and

- - plasma. 
by the monoclonal antibody mixture 1 were similarly expressed on isolated HDL and on native apolipoprotein A-I-containing particles in the plasma. However, a difference in epitope expression was observed for isolated apolipoprotein A-I. The polyclonal antibodies, on the other hand, recognized delipidated apolipoprotein A-I as well as apolipoprotein A-I on plasma HDL (fig. 4).

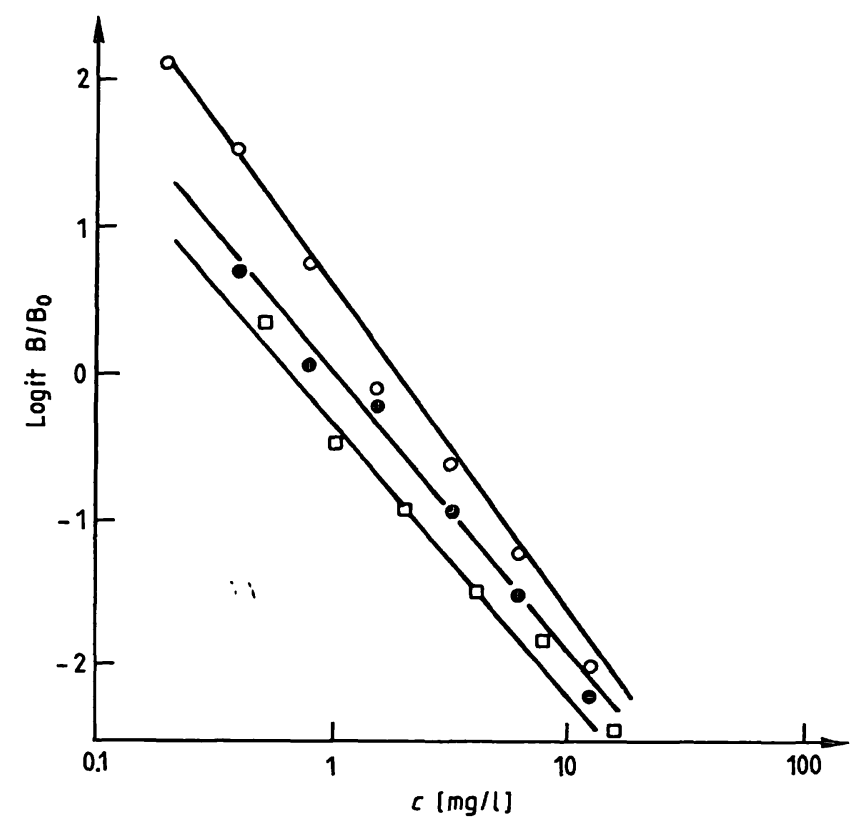

Fig. 4. Competitive inhibition of binding of $\left[{ }^{125} I\right] \mathrm{HDL}$ to immobilized polyclonal antibodies by

O-O HDL

$\square-\square$ apolipoprotein A-I and - - plasma.
Labeled monoclonal antibody mixture 2

The monoclonal antibodies selected for the labeled mixture 2 must be able to bind to apolipoprotein AI captured by the immobilized monoclonal antibody mixture 1 . We tested the ability of fourteen ${ }^{125}$ I-labeled monoclonal antibodies to bind to apolipoprotein AI-HDL already captured by immốbilized antibodies $\mathrm{A} 05, \mathrm{~A} 17$ and A30. Only the labeled monoclonal antibodies with high affinity apolipoprotein A-I binding are shown in figure 5. It is noted that the labeled A05 and A17 bound weakly to apolipoprotein A-I HDL captured by their respective non-labeled antibody. However, labeled A05 and A17 were able to reveal apolipoprotein A-I bound to other antibodies. Due to their high binding capacity monoclonal antibodies $\mathrm{A} 03$ and A51 were included in the mixture 2 .

\section{Immunoenzymometric assay}

\section{Optimization of the method}

With antibodies A05, A17 and A30 in an equimolar ratio as the solid-phase, we tested increasing concentrations of horseradish peroxidase-labeled monoclonal antibody mixture 2 , which contained an equimolar ratio of labeled A03, A05, A17 and A51. Using a 15000 -fold dilution of mixture 2, we obtained a standard curve with the same slope and sensitivity as the polyclonal antibodies as shown in figure 6 (12).
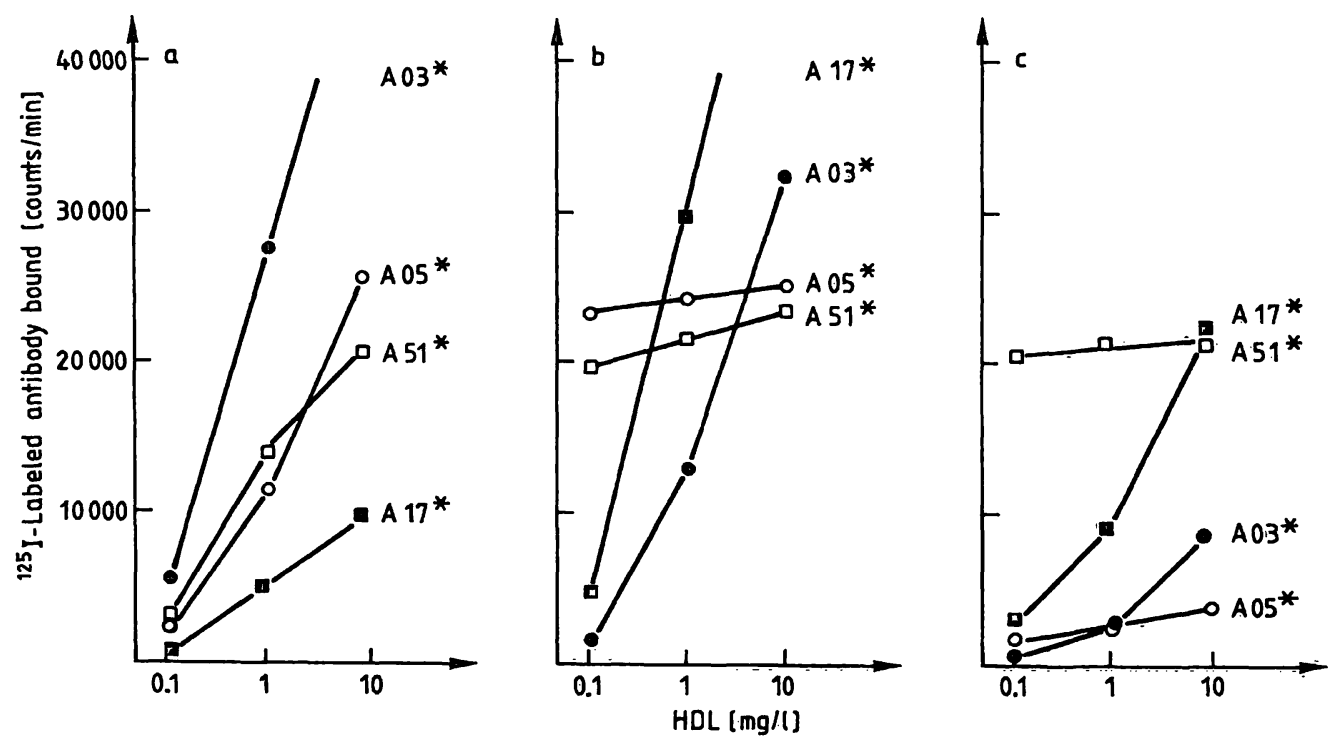

Fig. 5. Capacity of labeled monoclonal antibodies used in the mixture 2 to bind to apolipoprotein A-I captured by immobilized monoclonal antibodies in solid-phase.

a) solid phase: A17

b) solid phase: $A 30$

c) solid phase: A05

A03* etc $=$ labeled monoclonal antibody 


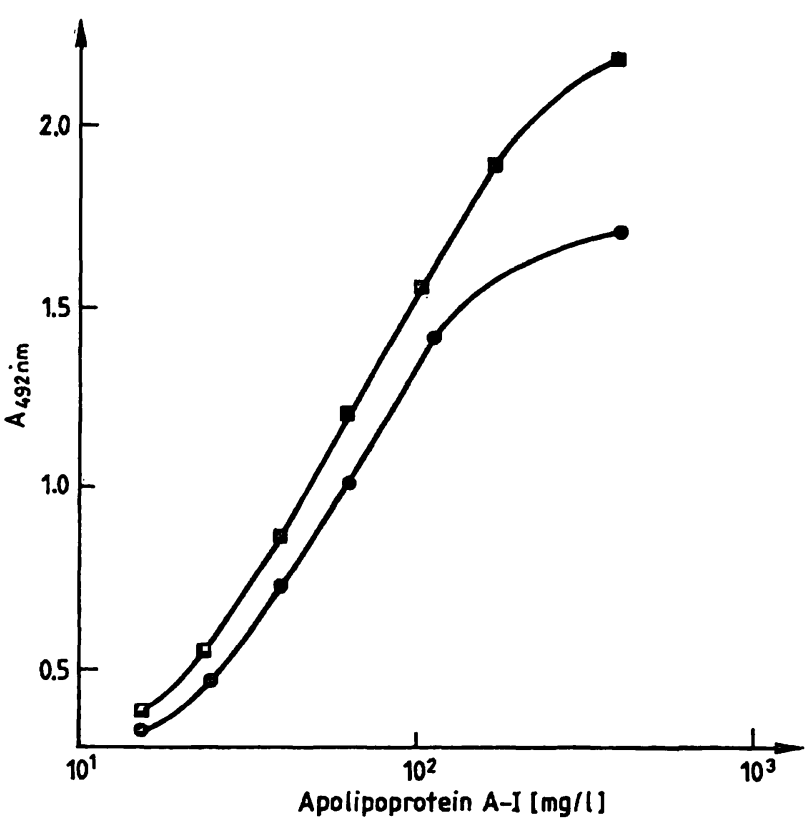

Fig. 6. Standard curves for the quantitation of human apolipoprotein A-I in the plasma determined by polyclonal

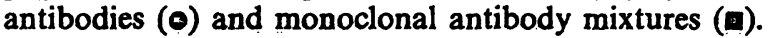
The secondary standard used for the comparison of the curves was a frozen pool of different plasmas.

We note that monoclonal antibody mixtures could potentially quantify more than the polyclonal antibodies but the curve slopes were identical.

Comparative study of calibration curve with hyperlipidaemic plasmas

Using the immunoenzymometric method, we studied the reaction curves of hypertriglyceridaemic, hypercholesterolaemic and frozen plasma, in order to compare the slopes of the curves with those for normal plasma (fig. $7 \mathrm{a}$ and $7 \mathrm{~b}$ ). We observed no modification in the curve of these pathologic plasmas, indicating that the recognition of the epitopes was identical in all apolipoprotein A-I-containing particles.

Tab. 1. Intra- and inter-assay variability of the ELISA for apolipoprotein $\dot{A}-\dot{I}$, using the monoclonal antibody.

\begin{tabular}{|c|c|c|c|c|}
\hline & $\begin{array}{l}\text { Plasma } \\
1\end{array}$ & $\begin{array}{l}\text { Plasma } \\
2\end{array}$ & $\begin{array}{l}\text { Plasma } \\
3\end{array}$ & $\begin{array}{l}\text { Plasma } \\
4\end{array}$ \\
\hline İntra-Assay & & & & \\
\hline 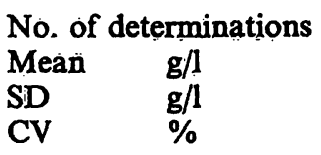 & $\begin{array}{l}33 \\
1.07 \\
0.077 \\
7.0\end{array}$ & $\begin{array}{l}33 \\
1.09 \\
0.059 \\
5.4\end{array}$ & $\begin{array}{l}27 \\
1.25 \\
0.059 \\
4.7\end{array}$ & $\begin{array}{l}30 \\
1.35 \\
0.059 \\
4.3\end{array}$ \\
\hline \multicolumn{5}{|l|}{ Inter-assay } \\
\hline $\begin{array}{l}\text { Mean } \\
\text { SD } \\
\text { CV }\end{array}$ & $\begin{array}{l}1.08 \\
0.088 \\
8.1\end{array}$ & $\begin{array}{l}1.10 \\
0.094 \\
8.5\end{array}$ & $\begin{array}{l}1.38 \\
0.112 \\
8.1\end{array}$ & $\begin{array}{l}1.39 \\
0.167 \\
12.1\end{array}$ \\
\hline
\end{tabular}
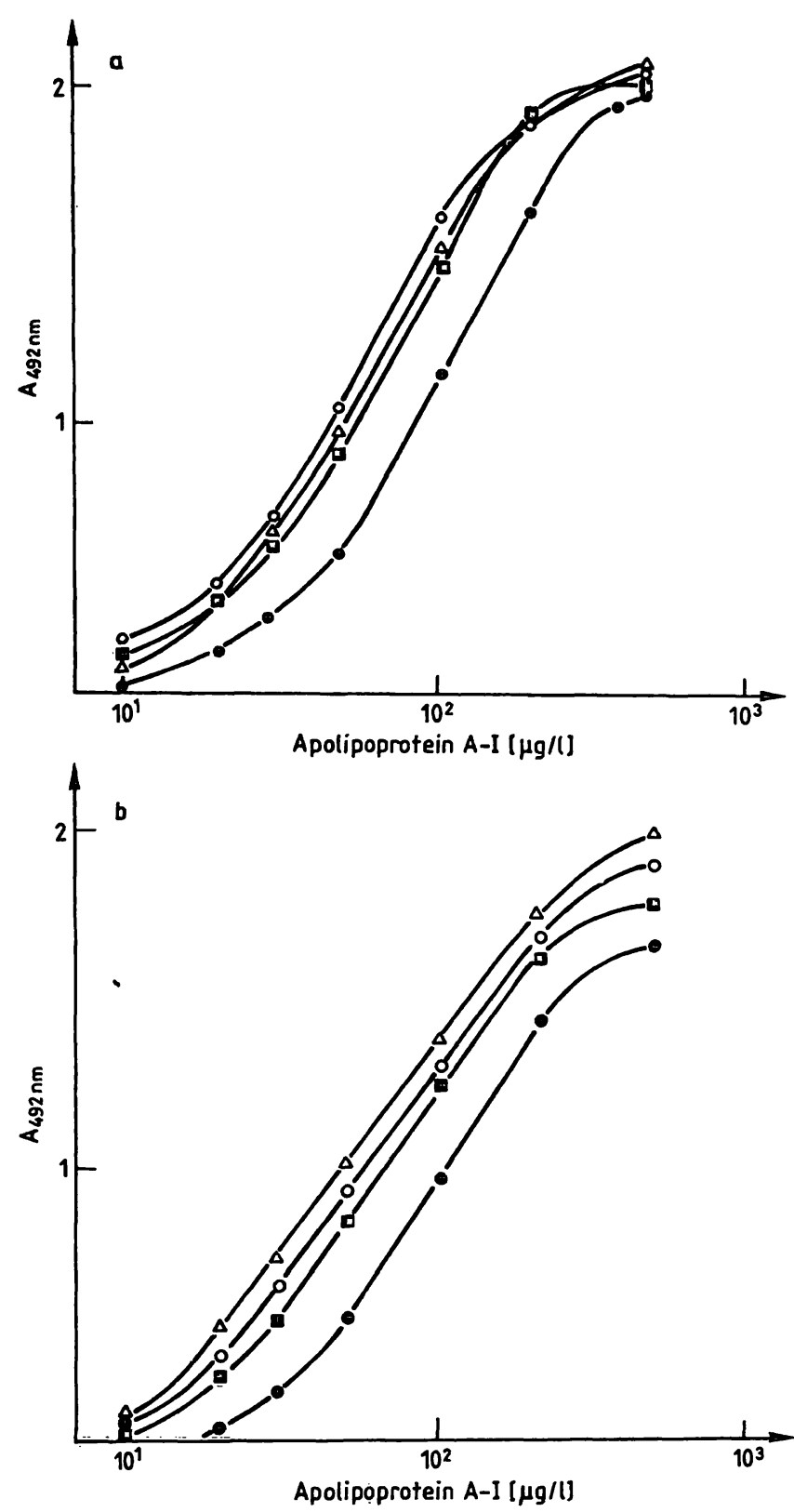

Fig. 7. Quantitative determination of human apolipoprotein A-I in hypertriglyceridaemic (O), hypercholesterolaemic $(\Delta)$, normal $(\square)$ and frozen $(\bullet)$ plasmas with monoclonal antibodies (a) and polyclonal antibodies (b). Whatever the concentration of apolipoprotein A-I in the plasmas, the slopes of the curves were maintained definitely parallel, although the curves themselves were related to the initial concentration of apolipoprotein A-I.

\section{Validation of assays for plasma apolipoprotein $A-I$}

The precision of the method was explored by measuring the apolipoprotein A-I of four plasmas 27 to 33 times on the same plate to obtain the within assay coefficient of variation. These same four plasmas were assayed on 5 different days to give the between assay coefficient of variation. The results, summarized in table 1 , indicate that the experimental variation of the apolipoprotein A-I determination is similar when performed with monoclonal antibody mixtures or with the polyclonal antibody described previously. 
Tab. 2. Effect of storage time and temperature on plasma apolipoprotein A-I.

\begin{tabular}{|c|c|c|c|c|c|c|c|c|}
\hline \multirow{3}{*}{$\begin{array}{l}\text { Storage } \\
\text { Days: } \\
\text { Temperature }\end{array}$} & \multicolumn{8}{|c|}{ Plasma } \\
\hline & 1 & 2 & 3 & 4 & 5 & 6 & 7 & 8 \\
\hline & \multicolumn{6}{|c|}{ Apolipoprotein A-I $(\mathrm{g} / \mathrm{l})$} & \multicolumn{2}{|c|}{$\because$} \\
\hline $\begin{array}{lr}0: & 20^{\circ} \mathrm{C} \\
1: & 4^{\circ} \mathrm{C} \\
7: & 4^{\circ} \mathrm{C} \\
7: & -20^{\circ} \mathrm{C} \\
7: & -80^{\circ} \mathrm{C}\end{array}$ & $\begin{array}{l}1.35 \\
1.28 \\
1.20 \\
1.30 \\
1.22\end{array}$ & $\begin{array}{l}1.07 \\
0.97 \\
0.95 \\
1.00 \\
1.10\end{array}$ & $\begin{array}{l}1.32 \\
1.21 \\
1.24 \\
1.25 \\
1.10\end{array}$ & $\begin{array}{l}1.25 \\
1.15 \\
1.40 \\
1.15 \\
1.37\end{array}$ & $\begin{array}{l}0.97 \\
1.10 \\
0.84 \\
0.87 \\
1.00\end{array}$ & $\begin{array}{l}0.95 \\
0.87 \\
1.07 \\
1.05 \\
0.90\end{array}$ & $\begin{array}{l}1.45 \\
1.32 \\
1.35 \\
1.27 \\
1.40\end{array}$ & $\begin{array}{l}1.25 \\
1.37 \\
1.10 \\
1.45 \\
1.30\end{array}$ \\
\hline $\begin{array}{l}\text { Mean } \\
\text { CV (\%) }\end{array}$ & $\begin{array}{l}1.27 \\
4.70\end{array}$ & $\begin{array}{l}1.10 \\
6.30\end{array}$ & $\begin{array}{l}1.22 \\
6.50\end{array}$ & $\begin{array}{l}1.26 \\
9.30\end{array}$ & $\begin{array}{c}95 \\
10.9\end{array}$ & $\begin{array}{l}0.96 \\
9.20\end{array}$ & $\begin{array}{l}1.35 \\
5.10\end{array}$ & $\begin{array}{c}1.29 \\
10.2\end{array}$ \\
\hline
\end{tabular}

Effect of storage time and temperature on the plasma apolipoprotein A-I determination

Because the immunoreactivity of one monoclonal antibody against apolipoprotein A-I could change with storage of serum at $4^{\circ} \mathrm{C}(24)$, we investigated the effect of storage and freezing on the plasma apolipoprotein A-I content. No significant changes in apolipoprotein $\mathrm{A}-\mathrm{I}$ determinations were registered when the plasmas $(\mathrm{n}=8)$ were stored at $4{ }^{\circ} \mathrm{C},-20^{\circ} \mathrm{C}$ or $-80^{\circ} \mathrm{C}$ (tab. 2).

Correlation between apolipoprotein A-I concentrations as determined by our two immunoenzymometric assays

The concentrations of apolipoprotein A-I in the plasma, as determined by immunoenzymoassay with the monoclonal mixtures, correlate highly with the concentrations of apolipoprotein A-I as determined in the polyclonal immunoenzymoassay. The correla-

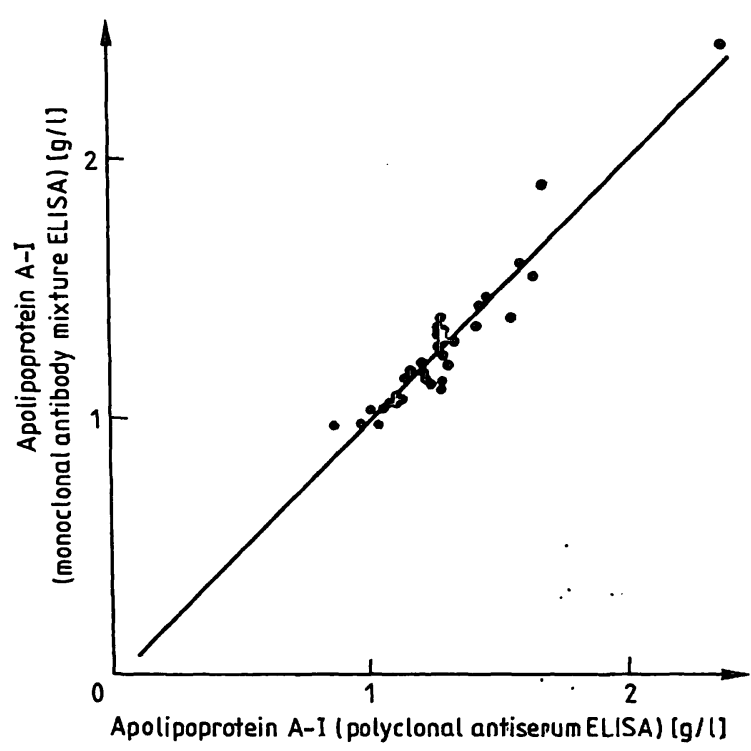

Fig. 8. Correlation between human apolipoprotein $A=I$ concentrations as determined by polyclonal antibodies $(\mathrm{m}=1.29 \mathrm{~g} / \mathrm{l})$ and monoclonal antibody mixtures $(\mathrm{m}=1.28 \mathrm{~g} / \mathrm{l})$ in sandwich ELISA. The equation of the regression line is:

$\mathrm{y}=1.035 \mathrm{x}-0.045 ; \mathrm{r}=0.96$ and $\mathrm{n}=35$ tion coefficient of 0.96 between these two immunoenzymoassays was good. The equation of the regression line was given in figure 8 .

\section{Discussion}

Numerous epidemiologic studies have established the role of human plasma apolipoprotein A-I in cholesterol esterification and transport (25-28). Such a role is consistent with apolipoprotein A-I as a negative risk factor for coronary artery disease.

The measurement of human plasma apolipoprotein A-I is therefore of considerable clinical interest. However, despite efforts and an extensive literature, measurement of this apolipoprotein has presented difficulties. Measurements are influenced by the antigenic site specificities of the antisera $(13,14)$, standardization and the methodology employed in a particular assay system. Consequently, there is the possibility of considerable bias between laboratories or even within the same laboratory during long-term studies.

The potential advantages of the immunoenzymometric assay for apolipoprotein measurements have been well documented $(15,16)$. The use of mixture of monoclonal antibodies reacting only with surface antigenic sites of apolipoprotein A-I expressed on native high density lipoprotein particles may offer distinct advantages with regard to standardization. These antibodies not only confirm the specificity of the assay system, but also ensure a constant source of unvarying antibody.

Apolipoprotein A-I has been shown to contain dif= ferent antigenic determinants $(26,27)$. In HDL particles, one segment is exposed or available to antibody, whereas another segment appears to be masked by lipids or other apolipoproteins (28). If the sample is tested against polyclonal antibody with reactivity to the unexposed determinants, the absolute amount of apolipoprotein A-I is underestimated. The sample is therefore often treated to maximize.immunoassayable 
apolipoprotein A-I. Due to the fact that the monoclonal antibodies used in our assay are surface-specific antibodies, such a treatment is not necessary and apolipoprotein A-I present in all the density fractions can be measured directly.

\section{References}

1. Avogaro, P., Bittolo Bon, G., Cazzolato, G. \& Quinci, G. B. (1979) Lancet I, $901-903$.

2. Fruchart, J. C., Kora, I., Cachera, C., Clavey, V., Duthilleul, P. \& Moschetto, Y. (1982) Clin. Chem. 28, 59-62.

3. De Backer, G., Rosseneu, M. \& Deslypere, J. P. (1982) Atherosclerosis 42, 197-203.

4. Riesen, W. F., Mordasini, R., Salzmann, C., Theler, A. \& Gurtner, H. P. (1980) Atherosclerosis 37, 157-162.

5. Maciejko, J. J., Holmes, D. R., Kottke, B. A., Zinsmeister, A. R., Dinh, D. M. \& Mao, S. J. T. (1983) N. Engl. J. Med. 309, 385-389.

6. Kladetzky, R. G., Assmann, G., Walgenbach, S., Tauchert, P. \& Helb, H. D. (1980) Artery 7, 191-205.

7. Cheung, M. C. \& Albers, J. J. (1983) NIH Publication $1266,258-264$

8. Curry, M. D., Alaupovic, P. \& Suenram, C. A. (1976) Clin. Chem. 22, 315-322.

9. Karlin, J. B., Juhn, D. J., \& Starr, J. T. (1976) J. Lipid Res. $17,30-37$.

10. Rosseneu, M., Vercaemst, R., Vinaimont, N., Van Tornout, P., Henderson, L. O. \& Herbert, P. N. (1981) Clin. Chem. $27,856-859$.

11. Bury, J. \& Rosseneu, M. (1985) Clin. Chem. 31, 247-251.

12. Koren, E., Puchois, P., McConathy, W. J., Fesmire, J. D. \& Alaupovic, P. (1985) Clin. Chim. Acta 147, 85-95.

13. Ayrault-Jarrier, M., Bobilewicz, D., Pastier, D., Beucler, I. \& Polonovski, J. (1982) Ann. Biol. Clin. 40, 187-194.

14. Fesmire, J. D., McConathy, W. J. \& Alaupovic, P. (1984) Clin. Chem. 30, 712-716.

15. Report of the Workshop on Apolipoprotein Quantification (1983) NIH Publication 1266, 467.
Thus, the use of a uniformly accepted reference standard and of monoclonal antibodies in an immunoenzymometric assay permits standardization of a method, which could be of general use and suitable for screening purposes.

16. Fruchart, J. C., Puchois, P. \& Fievet, C. (1985) In: Methods of Enzymatic Analysis (Bergmeyer, H. U., ed.), Vol. III, pp. $126-138$.

17. Havel, R. J., Eder, H. A. \& Bragdon, J. H. (1955) J. Clin. Invest. 34, 1345-1353.

18. Mezdour, H., Clavey, V., Kora, I., Koffigan, M., Barkia, A. \& Fruchart, J. C. (1987) J. Chromatography 414, 3545

19. Campbell, A. M. (1984) Elsevier Eds. Amsterdam, New York, Oxford.

20. Bahr, G. M., Rook, G. A. W., Moreno, E., Lydyard, P. M., Modabber, F. Z. \& Stanford J. L. (1980) Immunology 41 865-873.

21. Towbin, H., Staehelin, T. \& Gordon, J. (1979) Proc. Natl Acad. Sci. USA 76, 4350-4354.

22. McFarlane, H. S. (1964) In: Mammalian protein metabolism (Munro, M. W. \& Allison, J. B., eds.), New York, Academic Press, pp. 331-342.

23. Greenwood, F. C., Hunter, W. M. \& Glover, J. S. (1963) Biochem. J. 89, 114-123.

24. Milthorp, P., Weech, P. K., Milne, R. W. \& Marcel, Y. L. (1986) Arterosclerosis 6, 285-296.

25. Brunzell, J. D., Sniderman, A. D., Albers, J. J. \& Kwiterovich, P. O. (1984) Arterosclerosis 4, 79-83.

26. Curtiss, L. K. \& Edgington, T. S. (1985) J. Biol. Chem. 260, 2982-2993.

27. Weech, P. K., Milne, R. W., Milthorp, P. \& Marcel, Y. L. (1985) Biochim. Biophys. Acta 835, 390-401.

28. Mao, S. J. T., Miller, J. P., Gotto, A. \& Sparrow, J. T. (1980) J. Biol: Chem. 255, 3448-3452.

Professeur J.-C. Fruchart

Serlia Institut Pasteur

1 , rue du Pr. Calmette

F-59019 Lille Cédex 
